Research Report No. 38/2012

\title{
Old Lessons for New Governance: Safety or Profit and the New Conventional Wisdom
}

Eric Tucker

Osgoode Hall Law School of York University, etucker@yorku.ca

Follow this and additional works at: http:// digitalcommons.osgoode.yorku.ca/clpe

\section{Recommended Citation}

Tucker, Eric, "Old Lessons for New Governance: Safety or Profit and the New Conventional Wisdom" (2012). Comparative Research in Law \& Political Economy. Research Paper No. 38/2012.

http://digitalcommons.osgoode.yorku.ca/clpe/37 


\section{OSGOODE}

OSGOODE HALL LAW SCHOOL

YOR K U N I VERSITY

\section{OSGOODE HALL LAW SCHOOL}

Comparative Research in Law \& Political Economy

RESEARCH PAPER SERIES

Research Paper No. 38/2012

Old Lessons for New Governance: Safety or Profit and the New Conventional Wisdom

Eric Tucker

Editors:

Peer Zumbansen (Osgoode Hall Law School, Toronto, Director, Comparative Research in Law and Political Economy)

John W. Cioffi (University of California at Riverside)

Leeanne Footman (Osgoode Hall Law School, Toronto, Production Editor)

Comparative Research in Law \& Political Economy 


\author{
Osgoode CLPE Research Paper 38/2012 \\ Vol. 08 No. 08 (2012) \\ Eric Tucker
}

\title{
Old Lessons for New Governance: Safety or Profit and the New Conventional Wisdom
}

\begin{abstract}
New governance theory has a large following in academia and is exerting an influence in numerous spheres of regulatory policy. Yet in the area of occupational health and safety, new governance is hardly new at all. Indeed, it is fair to say that it in many ways what are now labelled new governance concepts were first articulated and applied in the 1972 Robens Report, Safety and Health at Work. This included its critique of command and control legislation and its emphasis on the need to develop better self-regulation. This paper critically examines new governance models in OHS regulation. In the first part, I construct some ideal types of OHS regimes based on three variables; state protection, worker participation and employer management systems. These are used as heuristics in subsequent discussion. The second part briefly discusses the roots of new governance in the Robens report (referred to as 'old' new governance) and briefly reviews Ontario's experience with it, to examine its dynamics and its vulnerability to regress toward neoliberal self regulation/ paternalism in the absence of effective worker OHS activism. In part three, I focus on recent work by two North American new governance theorists, Orly Lobel and Cynthia Estlund, who consciously wish avoid a collapse of new governance approaches into neo-liberal self regulation/paternalism. I argue that despite their aspirations, the new governance prescriptions they embrace are unlikely to be institutionalized with the protective conditions they advocate and that their emphasis on self-regulation valorizes a movement toward the destination they wish to avoid. Finally, I ask whether degradation toward neo-liberal self-regulation/paternalism is inevitable and if not whether a progressive new governance theory is possible and has anything to offer toward strengthening a regime of public regulation under the unfavourable conditions that prevail today.
\end{abstract}

Key words: Regulation, Governance, Labour, Employment, Health, Safety, Work, Occupational Health and Safety 
New governance theory has a large following in academia and is influential in numerous spheres of regulatory policy. ${ }^{1}$ Yet in the area of occupational health and safety, new governance is hardly new at all. Indeed, it is fair to say that it in many ways what are now labelled new governance concepts were first articulated and applied in the 1972 Robens Report, Safety and Health at Work. This included its critique of command and control legislation and its emphasis on the development of better self-regulation. ${ }^{2}$ Thus it is particularly fitting that we return to Theo Nichols and Pete Armstrong's early critique of the Robens Report for some old lessons for new governance in occupational health and safety (OHS) regulation. While much of their monograph criticized the Robens Report for blaming apathy as the underlying source of workplace injuries (which justified its call for more self-regulation), Nichols and Armstrong's response was that a proper understanding of risk creation had to take as its starting point the pressure for production generated within capitalist relations of production. From their political economy perspective, the central regulatory problem was how to counteract the pressure to prioritize production over safety, and their solution required shifting power over production to workers on the shop floor. ${ }^{3}$

Clearly, the terms of the debate over OHS regulation have not remained static in the nearly forty years that have passed since their intervention; nor have the economic,

\footnotetext{
${ }^{1}$ For a critical discussion of the roots of governance theory and its dispersion across policy networks, see Jonathan S. Davies, Challenging Governance Theory (Bristol: Polity Press, 2011).

2 Safety and Health at Work, Report of the Committee 1970-72, Chair Lord Robens, (London: Cmnd 5034 1972), para. 41. ("The most fundamental conclusion to which our investigations have led is this. There are severe practical limits on the extent to which progressively better standards of safety and health at work can be brought about through negative regulation by external agencies. We need a more effectively self-regulating system." (emphasis in the original))

${ }^{3}$ Theo Nichols and Pete Armstrong, Safety or Profit: Industrial Accidents \& the Conventional Wisdom (Bristol: Flling Wall Press, 1973).
} 
political and social conditions of production. Thus the goal of this chapter is to follow the growth and development of new governance thinking about OHS, but at the same time, and in the spirit of Nichols and Armstrong, to critically examine the underlying assumptions new governance theorists make about the world and the implications for their prescriptions if they are wrong, and to consider alternative reforms that focus on building public regulatory capacity.

The chapter proceeds in four parts. In the first, I construct some ideal types of OHS regimes based on three variables; state protection, worker participation and employer management systems. These are used as heuristics in subsequent discussion. The second part briefly discusses the roots of new governance in the Robens report (referred to as 'old' new governance) and briefly reviews Ontario's experience with it, to illuminate its dynamics and its vulnerability to regress toward neo-liberal self regulation/paternalism in the absence of effective worker OHS activism. In part three, I focus on recent work by two North American new governance theorists, Orly Lobel and Cynthia Estlund, who consciously wish to avoid a collapse of new governance approaches into neo-liberal self regulation/paternalism. I argue that despite their aspirations, the new governance prescriptions they embrace are unlikely to be institutionalized with the protective conditions they advocate and that their emphasis on self-regulation valorizes a movement toward the destination they wish to avoid. Finally, I ask whether degradation toward neoliberal self-regulation/paternalism is inevitable and, if not, whether a progressive new governance theory that aims to strengthen a regime of public regulation under the unfavourable conditions that prevail today provides a better alternative. 


\section{Constructing Ideal Types}

For the purpose of locating new governance theories of OHS regulation within a range of possible configurations, it will be useful to construct some ideal types of regimes. In the past, I attempted to map out regimes of OHS regulation using two axes, state protection and worker participation. ${ }^{4}$ The focus of that study was on worker citizenship in the OHS regimes, not with OHS regulation more generally. That approach left out an important dimension of current regulatory practice, promotion of employer OHS management, which must be brought in if we are going to investigate new governance's emphasis on self-regulation. The term "OHS management" as used here does not refer specifically to the presence or absence of an occupational health and safety management systems defined as a "systematic managerial process to detect, abate and prevent workplace hazards." ${ }^{\prime 5}$ Rather, it refers to state policies that support the development of employer competence and commitment to manage OHS (other than by command and control regulation or strengthening worker participation). This might include education and promotional activities, support for the formation of sectoral safety associations and the use of economic incentives in the workers' compensation system, including experience and merit rating.

For the purposes of constructing ideal types I have adopted a binary weak/strong assessment for each element, although obviously this is a gross oversimplification that

\footnotetext{
${ }^{4}$ Tucker, "Re-Mapping Worker Citizenship in Contemporary Occupational Health and Safety Regimes," (2007) 37 International Journal of Health Services 145-70.

${ }^{5}$ Frick, Jensen, Quinlan and Wilthagen, "Systematic Occupational Helath and Safety Management - An Introduction to a New Strategy for Occupational Health and Safety Well-Being," in same eds. Systematic Occupational Health and Safety Management (2000), 1.
} 
ignores the enormous variation within actual regimes based on industry, region, etc. Table 1 presents the eight logically possible combinations.

Table 1: Ideal Types of OHS Regimes

\begin{tabular}{|c|l|l|l|l|l|l|l|l|}
\hline & $\begin{array}{l}\text { Laissez } \\
\text { Faire/Neo- } \\
\text { Liberal } \\
\text { Regime }\end{array}$ & $\begin{array}{l}\text { Paternalist } \\
\text { Promotional } \\
\text { Regime }\end{array}$ & $\begin{array}{l}\text { Worker } \\
\text { Participation } \\
\text { Regime }\end{array}$ & $\begin{array}{l}\text { Collective } \\
\text { Laissez- } \\
\text { Faire } \\
\text { Regime }\end{array}$ & $\begin{array}{l}\text { Command } \\
\text { and Control } \\
\text { Regime }\end{array}$ & $\begin{array}{l}\text { Command } \\
\text { and } \\
\text { Promote } \\
\text { Regime }\end{array}$ & $\begin{array}{l}\text { Workers' } \\
\text { Democracy } \\
\text { Regime }\end{array}$ & $\begin{array}{l}\text { Social } \\
\text { Democracy } \\
\text { Regime }\end{array}$ \\
\hline $\begin{array}{c}\text { State } \\
\text { Protection } \\
\text { (Command } \\
\text { and Control } \\
\text { Regulation) }\end{array}$ & Weak & Weak & Weak & Weak & Strong & Strong & Strong & Strong \\
\hline $\begin{array}{c}\text { Worker } \\
\text { Participation }\end{array}$ & Weak & Weak & Strong & Strong & Weak & Weak & Strong & Strong \\
\hline $\begin{array}{c}\text { Employer } \\
\text { OHS } \\
\text { Management }\end{array}$ & Weak & Strong & Weak & Strong & Weak & Strong & Weak & Strong \\
\hline
\end{tabular}

I am not particularly concerned to defend the labels I have attached to these ideal types but perhaps it is worth briefly explaining my thinking on them. The regimes can be divided into two clusters based on whether there is weak or strong state protection. Beginning with the former, in a laissez-faire or neo-liberal regime, the state does not actively support any of the three dimensions of OHS regulation. In this regime, it is unlikely that employer provision of high quality work environments will spontaneously emerge, notwithstanding the business-case arguments that are often made for it. ${ }^{6}$ The historical

\footnotetext{
${ }^{6}$ For a literature review of the business case, see Courtney Davis, Making Companies Safe: What Works? (Centre of Corporate Accountability 2004), 69-72. Also, see Susan Margaret Hart, "Self-regulation, Corporate Social Responsibility and the Business Case: Do They Work in Achieving Workplace Equality and Safety?" (2010), 92 Journal of Business Ethics 585; Peter Dorman, "If Safety Pays, Why Don't Employers Invest in It?" in Frick, Systematic, 351; Dave Johnson, "What Ever Happened to the Business Case for Safety?"(21 September 2005), 4:9 ISHN E-Zine, Online
} 
evidence for laissez-faire regimes that dominated much of the nineteenth century supports this view; workers were routinely exposed to highly dangerous conditions in mines, factories, and railways and suffered high rates of injury, disease and death. ${ }^{7}$ A similar conclusion can be reached about OHS management in a neo-liberal world when union representation and state regulation are declining and production is increasingly organized through diffuse contractual networks rather direct management of employees. ${ }^{8}$

For this reason, most states have chosen to intervene on at least one of the three dimensions of regulation. The regime that deviates least from the ideology and practice of laissez-faire or neo-liberalism operates by only promoting employer OHS management, typically through some combination of educational activities, support for the formation of employer safety associations, and the use of economic incentives in a workers' compensation system. I have labelled this kind of regime "paternalist promotional" insofar as it does not provide workers with any rights and operates primarily by encouraging management to behave responsibly. Arguably, this approach prevailed in the regulation of farm worker safety in Ontario before the occupational health and safety act was extended to agriculture in 2006. Farm workers neither enjoyed an entitlement to minimum OHS standards nor a right to participate in OHS management, but they were covered by the workers' compensation system, which supported a farm safety association and farm

http:/www.ishn.com/Articles/Newsletter Archive/d5b62bf8f644c010VgnVCM100000f932a8c0 (Accessed 11 April 2011).

${ }^{7}$ Tucker, Administering Danger in the Workplace (Toronto: University of Toronto Press, 1990); Mark Aldrich, Safety First (Baltimore: Johns Hopkins U.P. 1997); Donald W. Rogers, Making Capitalism Safe (Urbana and Chicago: University of Illinois Press, 2009).

${ }^{8}$ Nichols and Tucker, "OHS Management Systems in the United Kingdom and Ontario, Canada: A Political Economy Perspective" in Kaj Frick et al., eds. Systematic Occupational Health and Safety Management (Amsterdam: Pergamon, 2000) 285; Quinlan and Mayhew, "Precarious Employment, Work Re-Organization and the Fracturing of OHS Management," ibid 175. On the negative effects of neo-liberalism on OHS in the Baltic states, see Charles Woolfson and Matthias Beck, "Occupational Health and Safety in Transitional Lithuania" (2003), 34 Industrial Relations Journal 241. 
employers were experienced rated and so had economic incentives to reduce claims costs. Not surprisingly, this OHS regime performed poorly. ${ }^{9}$

A third regime in this cluster is one built primarily on strong worker participation rights that enable workers to exert a significant level of influence on and, perhaps, control over decision making that affects health and safety conditions at work. Strong worker participation regimes must be distinguished from weaker involvement schemes that are likely to be largely cosmetic and aim to secure worker compliance with management objectives. ${ }^{10}$ It is possible that strong worker participation will emerge in the absence of active state support where there is widespread and effective worker self-organization, but it is more common for participation rights to become generalized and entrenched through legislation requiring safety representatives and joint health and safety committees (JHSC). ${ }^{11}$ It is difficult, however, to think of any state which has constructed an OHS regime primarily around strong worker participation.

A more common route for states that wish to limit direct state regulation but hope to improve OHS outcomes is one I have labelled a collective laissez-faire regime. The term

\footnotetext{
${ }^{9}$ Eric Tucker, "Will the Vicious Circle of Precariousness be Unbroken?: The Exclusion of Ontario Farm Workers from the Occupational Health and Safety Act," in Leah Vosko, ed., Precarious Employment: Understanding Labour Market Insecurity in Canada (Montreal and Kingston: McGill-Queen's University Press, 2006), 256. On the exclusion of farm workers generally from labour protection in the U.S., and on the limited role of the federal Occupational Safety and Health Administration, see Greg Schell, "Farmworker Exceptionalism under the Law" in Charles D. Thompson and Melinda F. Wiggins, eds., Farmworkers' Lives, Labor and Advocacy (Austin: University of Texas Press, 2002), 139, esp. At 149-50. Arguably, a regime of this sort operated in Ontario after the enactment of a workers' compensation law in 1914, and successfully promoted OHS improvements. See Javier Silvestre, "Improving Workplace Safety in the Ontario Manufacturing Industry, 1914-1939" (2010), 84 Business History Review 527.

${ }^{10}$ For a helpful discussion, see Harry Taylor, "Insights into Participation from Critical Management and Labour Process Perspectives" in Bill Cooke and Uma Kothari, eds., Participation: The New Tyranny?(London: Zed Books, 2001), 122-38.

${ }^{11}$ For example, in Ontario miners negotiated JHSCs before they became mandatory at a time when direct state regulation of health hazards in the mines was quite weak. However, worker OHS representation only became widespread after the enactment of mandatory legislation. Tucker, "Remapping," 151.
} 
is borrowed from Kahn-Freund's characterization of the English regime of labour law, which he viewed as based on state support for the establishment of collective bargaining processes that allowed the parties maximum leeway to conclude and enforce their own agreements. $^{12}$ In the context of OHS regulation, the focus is on state support for bipartite regulation through the promotion of worker participation rights (including forms of collective representation) and employer safety associations. While it is difficult to identify a pure form of this model, as we shall see in the next section, regulatory bipartism has been attractive to some Robens- style OHS regimes. ${ }^{13}$

The second cluster of OHS regimes is based on strong state protection. A pure command and control model relies exclusively on direct state regulation. Although early health and safety laws fit this model in principle, the reality was that OHS standards were almost always qualified by considerations of what was practical and enforcement practices were based on persuasion rather than prosecution. ${ }^{14}$ Arguably, then, many of these regimes operated more in a paternalist promotional mode. However, to the extent that they combined strong direct state regulation with active support for employer management, they would fall into the model I have labelled a command and promote regime. Finally, I have labelled a regime that combines strong command and control regulation with support for worker participation a workers' democracy regime, and a regime that combines a strong version of all three a social democratic regime. Scandinavian models tended toward the last, as they supported strong employer OHS

\footnotetext{
${ }^{12}$ For a recent discussion of Kahn-Freund's approach, see Ruth Dukes, "Otto Kahn-Freund and Collective LaissezFaire: An Edifice without a Keystone?” (2009), 72 Modern Law Review 220.

${ }^{13}$ See Tucker, "Re-Mapping."

${ }^{14}$ For example, see Tucker, Administering Danger.
} 
organization in conjunction with worker participation rights to promote bipartite regulation with a strong state presence. ${ }^{15}$

It is important to re-emphasize that this is a table of ideal types, not actual historical or current examples of OHS regulation, which are always going to be more complex.

Nevertheless, I think it provides some useful heuristics for thinking about and comparing actual OHS regimes and, in particular, for understanding and ultimately assessing both 'old' and 'new' new governance approaches.

\section{‘Old’ New Governance}

As we noted, new governance theory in the realm of OHS regulation first became prominent in the Robens Report with its emphasis on the development of more effective self regulation. The role of the state was to create the conditions for this to occur. ${ }^{16}$ However, as I have argued elsewhere, Robens-inspired regimes of mandated partial self regulation were implemented in very different ways, depending on the degree of selfregulation permitted and on the substance of what was mandated, particularly in regard to requirements for worker participation. The political and economic context in which the regulation operated also significantly shaped the capacity and willingness of workers to exercise their participatory rights and the strength of state enforcement effort. Finally, the flexibility inherent in these regimes meant that they could be reconfigured without the

\footnotetext{
${ }^{15}$ Eric Tucker, "Worker Participation in Health and Safety Regulation: Lessons from Sweden," (1992) 37 Studies in Political Economy 95. For an illuminating discussion of the difference between collective laissez-faire and a more thoroughly social democratic model of regulation, as represented by the work of Hugo Sinzheimer, see Ruth Dukes, "Constitutionalizing Employment Relations: Sinzheimer, Kahn-Freund, and the Role of Labour Law" (2008), 35 Journal of Law and Society 341.

${ }^{16}$ Robens, para. 41.
} 
necessity of new legislation by administrative action and changes in worker and union leverage at the point of production. The result was that the regime was always a political project in the making, subject to the competing objectives of workers and employers and, therefore, likely to experience recurring conflict over its design and implementation, at least as long as workers were actively engaged in pushing for stronger protection or participation. ${ }^{17}$

In Ontario the Ham Report (1978) called for legislation to promote internal responsibility systems (IRS) that delineated the responsibilities of employers, supervisors and workers and that granted workers rights to know about workplace hazards, to participate in OHS management through joint health and safety committees (JHSCs) or, in smaller workplaces, through safety representatives, and to refuse unsafe work. The IRS was to be the primary site of regulation, with the external responsibility system (ERS) of enforceable standards, inspections, and prosecutions to provide a backup in instances where the IRS failed. In short, Ham's recommendations aimed to institutionalize a regime that most closely resembled collective laissez-faire, albeit one in which worker participation rights were rather limited. ${ }^{18}$

The legislation that followed, however, did not simply enact the Ham Commission recommendations. Rather than being an apolitical measure implementing expert recommendations, the entire exercise, from the appointment of the Commission to the enactment of legislation, was shaped by conflict between a strong worker OHS movement

\footnotetext{
${ }^{17}$ Tucker, "Re-Mapping Worker Citizenship in Contemporary Occupational Health and Safety Regimes," (2007) 37 International Journal of Health Services 145; "The Politics of Occupational Health and Safety in a Cold Climate: Diverging Trends in Worker Protection and Participation in Canada, 1985-2000," (2003) 58 Relations Industrielles/Industrial Relations 395; "Worker Participation in Health and Safety Regulation: Lessons from Sweden," (1992) 37 Studies in Political Economy 95.

${ }^{18}$ Ontario, Report of the Royal Commission on the Health and Safety of Workers in Mines (James M. Ham, Commissioner) (Toronto: Ministry of the Attorney General, 1976).
} 
that was pressuring the government to address serious OHS hazards that it was publicizing on an ongoing basis and an employer lobby that was resistant to encroachments on managerial prerogatives. The resulting OHS legislation was shaped by these pressures, but also aimed to contain them. ${ }^{19}$ It promoted self regulation through the IRS with a secondary role for direct state protection. This approach did not calm the political waters, as worker OHS activists often found management resistant to addressing their health and safety concerns and the state reluctant to enforce the law. In response, workers called for legislation to increase their power within the IRS and to strengthen the ERS - a regime more akin to the worker democracy model. ${ }^{20}$ More pressure on the government led to legislative revisions in 1990 that better institutionalized worker participation by mandating more procedural requirements for JHSCs, but did not expand the powers of committees or increase the strength of worker rights. The law also expanded regulatory bipartism by providing for worker-management oversight of health and safety training in the province. Finally, maximum penalties for violations were substantially increased. ${ }^{21}$ Overall, there was some movement toward a social democratic model, but the extent of the change was modest.

Ironically, the election of a labour friendly New Democratic Party government in 1990, shortly after the enactment of the OHS reforms, was accompanied by less, not more

\footnotetext{
${ }^{19}$ Robert Storey and Eric Tucker, "All that is Solid Melts into Air: Worker Participation and Occupational Health and Safety Regulation in Ontario, 1970-2000," in Vernon Mogensen, ed., Worker Safety Under Siege (Armonk, NY: M.E. Sharpe, 2006), 157-86.

${ }^{20}$ Richard Fidler, "The Occupational Health and Safety Act and the Internal Responsibility System,” (1985) 24 Osgoode Hall Law Journal 315; Doug Smith, Consulted to Death (Winnipeg, Arbeiter Ring, 2000); Storey and Tucker,

${ }^{21}$ S.O. 1990 , c. 7.
} 
enforcement. Moreover, the militant worker OHS movement that had been so effective over the previous fifteen years or so began to weaken, perhaps in part because trade union officials did not want to embarrass 'their' government and in part because of the economic recession of the early 1990s not only made other workplace issues more pressing, but also increased the level of job fear. In many ways, it began to look as if Ontario was going to go down the path followed in the UK under New Labour ${ }^{22}$ but, as we shall see in the final section of the paper, it did not.

The lessons from Ontario's experience of 'old' new governance accord well with Nichols and Armstrong's political-economy analysis. First, worker OHS activism was absolutely essential to the initiation of change. Second, that activism significantly shaped the reform legislation; in the absence of political pressure from workers, the Ontario regime would have been more paternalistic, in that the mandated IRS would provided for weaker worker participation and state enforcement. ${ }^{23}$ Worker OHS activism pushed the model incrementally closer toward the worker or social democratic model. Third, continuing worker OHS activism was necessary to prevent the regime form degrading into a neo-liberal/paternalist regime, in which health and safety would be constructed according to management perspectives on what was reasonable given the cost constraints under which management operated (profit over safety). Instead, activist workers were able to turn JHSCs into arenas where independent worker voices exerted some influence on management decisions. ${ }^{24}$ Fourth, continuing worker OHS activism was responsible for

\footnotetext{
${ }^{22}$ Steve Tombs and David Whyte, "A Deadly Consensus: Worker Safety and Regulatory Degradation uner New Labour" (2010) 50 British Journal of Criminology 46, 50-61.

${ }^{23}$ For example, in the interim legislation, passed in 1976, JHSCs were only required when ordered by the ministry. S.O. 1976, c. 79.

${ }^{24}$ Alan Hall, Anne Forrest, Alan Sears and Niki Carlan, "Making a Difference: Knowledge Activism and Worker Representation in Joint OHS Committees," (2006) 61 Relations Industrielles 408.
} 
pushing the government to strengthen worker participation rights, even if only in the direction of better institutionalizing worker voice in the IRS and the ERS but without giving workers more power. Finally, the election of a so-called labour-friendly government did not guarantee that labour-friendly policies and practices would be implemented. As a result, continued worker mobilization and pressure was essential to prevent regulatory backsliding. Finally, as worker OHS activism declined, the regime slipped back towards paternalism.

\section{'New' New Governance}

The Robens Report's emphasis on the limited capacity of the state and the need to promote more responsible self-regulation lies at the heart of new governance theory, which has since been elaborated and given additional theoretical justifications. When addressing the limits of traditional command and control regulation, new governance theorists emphasize the growing complexity of the external environment and the increasing speed of technological and organizational innovation. This, they argue, overloads the capacity of states to gather and process the information necessary to develop effective regulations. They also emphasize that processes of globalization are hollowing out the ability of national states to effectively regulate globalized activities and that supranational regulatory institutions are too underdeveloped to fill the void. Moreover, they posit that command and control strategies are self-defeating. The imposition of substantive standards creates rigidities both in law and in the social fields that regulation is attempting to control. Existing regulation is likely to become quickly outdated and 
irrelevant, producing both the phenomenon of over-regulation of old hazards and underregulation of new and emerging ones. Finally, the targets of regulation increasingly resist what regulation there is and oppose new regulation, thus further limiting the state's capacity to respond to changes in the work environment, rendering it even less effective. In short, they say, we have a vicious circle. Not only does command and control regulation impair the capacity and motivation of private actors to solve problems on their own and reduce economic efficiency, but it also fails to achieve its normative goals. Workers and employers are both made worse off. ${ }^{25}$

Much of this narrative might also fit within a neo-liberal critique of traditional regulation, but new governance theorists insist they are not abandoning the normative goal of improved OHS outcomes to the naked pursuit of efficiency within an increasingly competitive global economy. Rather, they claim that new governance theory provides an approach to regulation that steers a third-way between command-and-control regulation, on the one hand, and neo-liberalism, on the other. A variety of names have been appended to this approach including reflexive regulation; responsive regulation and regulated selfregulation, amongst others. ${ }^{26}$ Although there are variations in emphasis, the focus of new governance is on steering corporate governance or management systems in socially desirable directions - other than by simply commanding them to behave in a prescribed ways. It is posited that law can facilitate more cooperative processes that are flexible, responsive and participatory, and that align the firm's interests with substantive regulatory

\footnotetext{
${ }^{25}$ The literature is vast. I have tended to focus on North American contributors, particularly Lobel and Estlund, whose work will be discussed in more detail, infra.

${ }^{26}$ Eg. Gunther Teubner, "Substantive and Reflexive Elements in Modern Law" (1983), 17 Law and Society Review 239; and Ian Ayres and John Braithwaite, Responsive Regulation: Transcending the Deregulation Debate (New York: Oxford University Press, 1992).
} 
goals that are not fundamentally altered by new governance methods. Tools include the use of incentives, increasing participation of stakeholders, requiring information sharing, and formal auditing, to name a few. A focus on networks and the identification of nodal points at which influence can be exerted, often by other private actors, is central to this approach. ${ }^{27}$

People who have been involved in OHS regulation for the past several decades might wonder, with good reason, whether new governance is worthy of the appellation "new". Not only are the roots of these ideas found in the Robens Report, but OHS regulation in many countries, including the UK and, as we have seen, Canada, has developed more or less along the regulatory track that new governance theorists are now elaborating, including mandatory disclosure of hazard information, mandated JHSCs and a reduced reliance on state standard setting and enforcement. For this reason, it is not surprising that new governance theorists have been attracted to current practices of OHS regulation as outstanding if imperfect examples of new governance theory in action.

In this regard, it is worth spending some time looking at Lobel's influential 2005 article, "Interlocking Regulatory and Industrial Relations: The Governance of Workplace Safety" ${ }^{28}$ since it provides insight into both the strengths and weaknesses of this kind of approach. Much of the article is devoted to documenting the failure of U.S. OHS regulation, pointing out that as a system of command and control it is incredibly ineffective: inspection resources are grossly inadequate; penalties for violating the law are paltry, and

\footnotetext{
${ }^{27}$ John Braithwaite, Regulatory Capitalism (Cheltanham: Edward Elgar Publishing, 2008). Also, see Davies, Challenging Governance, for a critical discussion of networked governance ideology and practice.

${ }^{28}$ (2005) 57 Administrative. Law Review 1071.
} 
prosecutions are rare. Moreover, the new world of work is increasing the difficulty of regulation because of accelerating innovation, vertical disintegration of firms and the corresponding growth of complex supply chains, and the challenge of addressing injuries that arise not from trauma but from job stresses and strains. What then is to be done? The overarching objective is to make OHS a shared interest that can be integrated into the core ends of economic enterprises. Regulatory agencies can achieve this by identifying the conditions under which effective self regulation works, promoting their development, and recognizing when those conditions are absent. ${ }^{29}$

Taking the case of the U.S. Occupational Safety and Health Administration (OSHA), Lobel identifies a number of voluntary compliance programs developed in the 1980s and 90s that signalled a shift away from command and control to a new governance model that fostered public/private partnership, encouraged industry cooperation, and allowed flexibility in policy implementation. ${ }^{30}$ However, she is also keenly aware that such a shift can also provide a cover for neo-liberal deregulation by allowing firms to escape even a weak threat of sanction for failure to achieve politically established regulatory standards. ${ }^{31}$ Therefore, Lobel argues, institutional arrangements must be put into place to avoid this result, and she identifies two principles, exit and voice, to guide this exercise. The exit principle requires the creation of a dual-track system of enforcement and sanctions so that firms are faced with a clear choice: if they fail to responsibly self regulate, they will be made subject to an effective, coercive command and control regime of enforcement. The threat of the big stick has to be credible. The voice principle requires effective worker participation

\footnotetext{
${ }^{29}$ Lobel, "Interlocking,"1104.

${ }^{30}$ Ibid., 1111.

${ }^{31}$ Kimberly D. Krawiec, "Cosmetic Compliance and the Failure of Negotiated Governance” (2003), 81 Washington University Law Quarterly 487.
} 
in the firm's occupational health and safety management system. This fits with new governance's emphasis on mobilizing non-governmental actors as a means for pressuring private corporations to act responsibly, even if this is not in the corporation's short-term economic interest.

On the face of it, Lobel's prescriptions resemble a social democratic model of OHS regulation insofar as she insists on the importance of a strong state to deal with laggards, worker participation in the design of regulated self regulation schemes and state support for employer OHS management. ${ }^{32}$ This is consistent with the position Lobel adopted in an earlier article, which identified three overarching projects intertwined in new governance theory: economic efficiency, political legitimacy and social democracy. Lobel noted that choices must be made and balances struck between these projects, but explicitly adopted a social democratic perspective, insisting that substantive commitments to the achievement of public ends must be maintained. ${ }^{33}$ But how difficult will that be?

The answer will depend to a great degree on the view taken of regulatory dilemmas in OHS and their resolution. ${ }^{34}$ In the political economy tradition, exemplified by Nichols and Armstrong, OHS regulation is seen as a realm of recurring regulatory dilemmas that stem from the relentless requirement within capitalism to produce for profit. To do this, capitalists must constantly pursue technological and organization innovation. This drive does not always lead to the creation of hazardous working conditions, but historically it

\footnotetext{
${ }^{32}$ Indeed, in earlier work she argued quite stronger for the view that new governance should be committed to the achievement of social democratic values. See Lobel, "The Renew Deal: The Fall of Regulation and the Rise of Governance in Contemporary Legal Thought” (2004), 89 Minnesota Law Review 262 at 387.

${ }^{33}$ Lobel, Renew Deal, 387.

${ }^{34}$ Eric Tucker, “Renorming Labour Law: Can We Escape Labour Law’s Recurring Regulatory Dilemmas?” (2010), 39 Industrial Law Journal 99.
} 
often has and presently it often does. But the fundamental point, as Nichols and Armstrong argued, is that there is systematic pressure within capitalist economies to privilege profitseeking over other objectives, including OHS, whenever those other objectives impose a barrier to the circulation and expansion of capital. The development of regulation for the benefit of working people ${ }^{35}$ involves the imposition of limits on the freedom of owners and managers of capital to engage in profit seeking at the expense of safety. As such, regulatory dilemmas will be a recurring phenomenon and must be considered from a class perspective, since at its core OHS regulation involves a conflict between those who want to impose limits on capital and capital's interest in maintaining maximum freedom to manage and control its activities in a self-interested way.

Erik Olin Wright's model of the conditions for class compromise suggests that positive class collaboration is possible within certain limits when workers have achieved a certain level of power. ${ }^{36}$ Apart from situations in which improved safety and profit maximization coincide, the fundamental condition is that working class organization must be sufficiently strong so that the costs to employers of cooperating with labour are lower than the costs of conflict. This can happen because worker organization, if it is sufficiently strong, can help employers overcome their collective action problem by, for example, imposing standardized conditions across an industry and reducing competitive pressures. Applied to OHS regulation, the argument would be that if workers, operating in conjunction with the state, can insure that all employers operate at the same high standard employers

\footnotetext{
${ }^{35}$ It is worth noting here that in Regulatory Capitalism Braithwaite emphasizes the ongoing role of regulation and therefore rejects the view that a neo-liberal order has emerged. What he ignores, however, is that the nature of regulatory capitalism has changed. Instead of regulation that restrains capitalism, we now have regulation that facilitates the growth of economic and social inequality. To make the persistence of regulation the central story while ignoring the shift in class power that neo-liberal policies have facilitated seems peculiar at best.

${ }^{36}$ Erik Olin Wright, "Working-Class Power, Capitalist-Class Interests, and Class Compromise" (2000) 105 American Journal of Sociology 957.
} 
will be more inclined to coregulate the work environment since they can be assured that their competitors will not gain an edge by producing less safely but more cheaply. Swedish models of OHS regulation in the 1970s and 1980s arguably went some way toward meeting this condition but as Swedish capital became more globalized in recent decades, workplace organization at the national level is less able to reduce competitive pressures. ${ }^{37}$

New governance theorists are not insensitive to the existence of conflicts of interest and unequal power relations but, like 'old' new governance theory, they generally seek to minimize their salience and avoid the need for trade-offs. The assumption of common interests in OHS deeply informed the Robens Report. "Indeed, there is a greater natural affinity of interest between 'the two sides' in relation to safety and health problems than in most other matters. There is no legitimate scope for 'bargaining' on safety and health issues, but much scope for constructive discussion, joint inspection, and participation in working out solutions." ${ }^{38}$ It is notable that Robens put the terms 'the two sides' and 'bargaining' in parentheses, seemingly to emphasize his doubt that there really were two sides that had something to bargain over. ${ }^{39}$ The report recommended worker participation, not to act as a check on management's penchant to stint on OHS, but rather to

\footnotetext{
${ }^{37}$ Kaj Frick, "Health and Safety Representation in Small Firms: A Swedish Success under Threat" in D. Walters and T. Nichols, eds., Workplace Health and Safety: International Perspectives on Worker Representation (Basingstoke, UK: Palgrave MacMillan, 2009): Eric Tucker, “"Worker Participation in Health and Safety Regulation: Lessons from Sweden," (1992) 37 Studies in Political Economy 95.

${ }^{38}$ Robens, para. 66.

${ }^{39}$ Robens, paras. 13, 28 and 41.
} 
encourage workers to accept "their full share of responsibility" and to monitor conditions for the purpose of providing information that employers would act upon. ${ }^{40}$

New new governance theorists have continued in this tradition of emphasizing common interests and margializing the significance of class conflict over OHS. ${ }^{41}$ For example, Lobel states, "Nonetheless, rich bases of ethnographies and comparative studies indicate that intense conflict between labor and capital around issues of occupational health and safety may be anomalous." She then quotes Robens for this proposition. ${ }^{42}$ Earlier in her article Lobel also addressed this issue in developing an argument that firms operated pursuant to a mixed set of motivations. However, even within that context, Lobel emphasized the business case for safety, taking into account the reduction of accident costs, including improved worker morale, reduced absenteeism, and consumer preference for goods and services that are produced safely.43

This last point links to an argument often found in 'new' new governance theory about the significance of reputational risk as a driver of firm behaviour. Here the argument is that a poor health and safety performance will negatively affect the firm's bottom line either because consumers will avoid its products or because other firms will not wish to do business with unsafe firms. Safety pays, at least most of the time, reducing the need to confront trade-offs between economic efficiency (profit) and social democratic values (worker safety). The assumption of common interests between workers and employers built on the business case for safety has a long history in OHS regulation going back to the

\footnotetext{
${ }^{40}$ Robens, para. 59. This view also informed the Ham Report which asserted (at 250) that health and safety was not a suitable issue for collective bargaining

${ }^{41}$ See Davies, Challenging Governance, who also emphasizes the ways in which governance and network theorists reject the continuing salience of class and class-based conflict.

${ }^{42}$ Lobel, "Interlocking," 1128. Notably the additional sources in her footnote on this point (fn. 274), do not for the most part provide empirical support for the common interest proposition.

${ }^{43}$ Ibid., 1102.
} 
factory acts and has often provided the basis for a subtle renorming of its objects toward the elimination of those risks that are excessive - from a business perspective. ${ }^{44}$

Notwithstanding the persistence of business case arguments, often found on government websites, the empirical evidence supporting the business case has been subject to much criticism and its limits identified. ${ }^{45}$

In addition to discounting the extent to which OHS conflicts with the profit motive, new governance theorists also tend to minimize the strength of the profit motive when conflicts do arise. In particular, there appears to be a high level of faith in the likelihood that virtue will triumph over self-interest. For example, in a recent discussion of restorative justice in the OHS context, Braithwaite describes restorative justice as a process that is "about sitting in a circle discussing who has been hurt and then the victim being able to describe in their own words how they are coping with the hurt and what they are looking for to repair that harm and prevent it from happening again. It is about the virtue of active responsibility as opposed to passive responsibility of holding someone responsible for what they have done in the past." If no one takes responsibility the circle is widened until a "softer target" - presumably the virtuous actor - is hit. ${ }^{46}$ Lobel also picks up on this strain of the new governance theory when she argues that "a cooperative governance framework can create empathy and mutual trust among diverse people." 47 Left here, we might think of this as an argument that virtue is immanent in business actors and

\footnotetext{
${ }^{44}$ Eric Tucker, Administering Danger in Workplace, 167-73.

${ }^{45}$ For an example of government promotion of the business case strategy, see http://www.hse.gov.uk/betterbusiness/large/index.htm. For critical assessments of the business case, see references at note 6 .

${ }^{46}$ Braithwaite, Regulatory Capitalism, 76-77.

${ }^{47}$ Lobel, "Interlocking," 1104.
} 
just needs a little nudging to be activated and to become the guiding principle for business decision-making. However, at least one empirical study has cast doubt on whether restorative justice responses influence behaviour. ${ }^{48}$ This result should not be surprising if one takes into account the ways in which unequal power relations in hierarchical organizations marked by real differences in motivations and goals of upper-level managers and lower-level workers undermine communication and may lead to the construction of hegemonic norms that shift responsibility from management to individual workers. ${ }^{49}$ Moreover, as Harry Glasbeek notes, “Given the corporation's recent historical role in the jettisoning of such job and income security as had been won...why should anyone believe that there will be a corporate drive to give back some of these gains? There is a limit to the extent that managers can indulge their personal sense of altruism and/or worker friendliness and still be true to their real task." ${ }^{\prime 50}$ And that real task, as corporate law scholars will tell you, is maximization of shareholder value, with all it entails. ${ }^{51}$

Because Lobel minimizes the salience of conflict and regulatory dilemmas, the OHS policy prescriptions she favours are problematic. Lobel endorses OSHA's efforts to promote cooperative compliance through a variety of two-track programs that exempt qualifying firms from regular inspections, although she recognizes that in the absence of a strong commitment to command and control regulation for firms that do not qualify for

\footnotetext{
${ }^{48}$ Vibeke Lehmann Nielsen and Christine Parker, "Testing Responsive Regulation in Regulatory Enforcement" (2009), 3 Regulation and Governance 376.

${ }^{49}$ Susan S. Silbey, "Taming Prometheus: Talk About Safety Culture" (2009) 35 Annual Review of Sociology 341 at 361-63; Heather M. Zoller, "Health on the Line: Identity and Disciplinary Control in Employee Occupational Health and Safety Discourse" (2003) 31 Journal of Applied Communication Research 118.

${ }^{50}$ Harry Glasbeek, "Book Review: Varieties of Capitalism, Corporate Governance and Employees" (2008), 22 Australian Journal of Corporate Law 293 at 303.

${ }^{51}$ Paddy Ireland, "Shareholder Primacy and the Distribution of Wealth" (2005), 68 Modern Law Review49.
} 
preferred treatment the model is likely to "become a guise for deregulation." ${ }^{2}$ As well, she is critical of the failure of OSHA's compliance programs to systematically include workers' voices and believes this too should be required. Her solution, then, includes elements of state protection and worker participation, but she provides little concrete guidance about how these should be structured, particularly in the context of pervasive and growing labour market inequalities. Indeed, her treatment of inequality is particularly disappointing, since it is entirely abstracted from capitalist relations of production. ${ }^{53}$ Against this background, Lobel's emphasizes cooperative programs and employer OHS management, with state enforcement and worker participation as contributors to the goal of better employer self-regulation. Yet she fails to confront the implications of prioritizing this track in a world in which these necessary supports are unlikely to materialize in the absence of concerted efforts to rebuild, legitimize and strengthen public enforcement and worker participation.

Here we might turn to Cynthia Estlund' recent book, Regoverning the Workplace. Estlund comes to new governance theory and regulated self-regulation as much out of despair as hope. She sees the death of old forms of workplace regulation as irreversible and more self-regulation as inevitable. Therefore, the question for her is whether it is possible to steer the development of self-regulation toward new forms of workplace governance in which workers have a real voice. Her book might be read as an internal

\footnotetext{
${ }^{52}$ Lobel, "Interlocking” 1114.

${ }^{53}$ Ibid, 1141-44.
} 
dialogue in which she tries, with only partial success, to convince herself that this is possible.

Her considerable reservations about new governance prescriptions derive from her better understanding of and greater focus on the realities of unequal power relations in the workplace than Lobel's. For example, although she treats OHS as an area in which there are sometimes common interests, and argues that common interests are more likely to exist in OHS than, for example, minimum wage or hours of work laws, she also recognizes that there will be occasions when "hazards...are integral to the production process and...serve the employer's bottom line" and that sometimes "health and safety improvements come with a significant price tag." 54

Because of a greater sensitivity to salience of power imbalances in the workplace, Estlund recognizes the vulnerability of employee committees to cooptation and intimidation given the fear of retaliation and job loss, even for unionized employees. ${ }^{55}$ Moreover, she also recognizes that internal committees are unlikely to effectively address hazards when they conflict with profit-making. So while safety committees can assist in some ways, for example, by aggregating and articulating employee knowledge about hazardous conditions where lack of communication is part of the problem, they need to operate in conjunction with some outside entity "that can supply power, independence, and protection against reprisals."56

\footnotetext{
${ }^{54}$ Cynthia Estlund, Regoverning the Workplace (New Haven: Yale University Press, 2010), 178.

${ }^{55}$ Estlund, Regoverning, 176. For a recent discussion of growing insecurity among workers with permanent, fulltime work and its negative effects on their health, see Wayne Lewchuk, Marlea Clarke, and Alice de Wolff, Working Without Commitments (Montreal and Kingston: McGill-Queen's University Press, 2011).

${ }^{56}$ Ibid. 179.
} 
Unfortunately, Estlund's proposals to meet that need are not very promising. Corporate codes of conduct with private independent monitoring and/or employee whistle-blower protection are proffered as part of the solution. The other piece is a two track enforcement regime built on a beefed-up enforcement track for firms that fail to selfregulate with the promise of a second track of less frequent inspection and reduced penalties for firms that have codes of conduct with independent monitors and protected worker participation. Expanded rights of action for work place injuries, retaliation for whistle-blowing and violations of health and safety laws firm this up.

Much has been written about the efficacy of corporate codes of conduct backed up by independent monitors in the context of global supply chains. Apart from questions about the independence of monitors and their effectiveness, there is a more fundamental concern with the logic of the model. In nearly every case, the motivation is the protection of reputational capital, and this is most heavily concentrated in highly branded firms that face a real threat of consumer pressure. While NGOs might be able to mobilize consumer opinion around the Nikes of this world, a broader dependence on voluntary and privately monitored codes seems unlikely to reach vast areas of the economy in which consumer branding does not play such a large role. ${ }^{57}$ Legislative measures imposing legal liabilities

\footnotetext{
${ }^{57}$ For a skeptical view, that also provides ample references to the literature, pro and con, see Harry Arthurs, "Corporate Self-Regulation: Political Economy, State Regulation and Reflexive Labour Law" in Cynthia Estlund and Brian Bercusson, eds., Regulating Labour in the Wake of Globalization: New Challenges, New Institutions (Oxford: Hart, 2009), 19.
} 
backed by meaningful inspection will often be required to achieve effective supply chain regulation. ${ }^{58}$

The alternative of depending on workers to blow the whistle on their employers is also problematic. Most health and safety acts currently protect workers against retaliation for exercising their statutory rights, including the right to refuse unsafe work, as well as to make complaints, but in the absence of a strong union most workers are unlikely to be assertive protagonists. This is amply illustrated by Neil Gunningham's recent work on the Australian mining industry which draws a very pessimistic view about the effectiveness of worker participation in a cold industrial relations climate. ${ }^{59}$ This returns Estlund to the conundrum of requiring the presence of the very conditions she stipulates as absent to make her alterative effective. As she recognizes, in their absence neo-liberal or paternalist regimes of regulation are far more probable outcomes than social democratic ones.

To the extent that the response to this weakness is the presence of a strong enforcement track that would induce firms to sign up to avoid facing its teeth, it presupposes the existence of one of the conditions whose absence has been identified as a driver of the turn to regulated self-regulation. If regulators lack the capacity both to identify which firms genuinely are on the right track and to detect OHS violations and appropriately sanction firms on the wrong track, regulated self-regulation is quite likely to degrade into neo-liberal self regulation/paternalism.

\footnotetext{
${ }^{58}$ David Walters and Phil James, "What Motivates Employers to Establish Preventive Management Arrangements within Supply Chains?” (2011), 49 Safety Science 988.

${ }^{59}$ Neil Gunningham, "Occupational Health and Safety, Worker Participation and the Mining Industry in a Changing World of Work” (2008) 29(3) Economic and Industrial Democracy 336. Also, see Michael Quinlan and Richard Johnstone, "The Implications of De-Collectivist Industrial Relations Laws and Associated Developments for Worker Health and Safety in Australia" (2009) 40 Industrial Relations Journal 426 and David Walters and Theo Nichols, Worker Representation and Workplace Health and Safety (Basingstoke: Palgrave Macmillan, 2007).
} 
Finally, Estlund's faith in the power of private litigation to create incentives for employers to comply with minimum standards laws is, perhaps, uniquely American. She is critical of the lack of avenues for private litigation for workplace injuries and OHS violations and calls for "activating the prodigious regulatory forces inside firms" by "arming...workers themselves...with their own regulatory arsenal" in the form of private actions. ${ }^{60}$ Although it is true that there has been an increase in employment litigation in the United States, it is hard to imagine that most workers, let alone vulnerable workers, are likely to benefit from private rights of action or that they will be an effective substitute for adequate public compensation and enforcement regimes.

So while there are differences among 'new' new governance theorists, the dominant tendency is to dissolve safety-profit conflicts by assuming common interests prevail and to minimize the extent to which profit-seeking behaviour will take precedence over safety considerations when conflicts do arise by assuming that virtue will tend to trump selfinterest. While more social democratic new governance theorists are quite cognizant that under conditions of unequal power relations new governance techniques face severe challenges and could be used to further disempower the weak, their call for safeguards still leaves in place a core agenda that favours more self-regulation and reliance on non-state actors. Moreover, they have already found that the safeguards they insist upon, state enforcement and worker voice, are irretrievably in decline. As a result, their shift in emphasis, from public to private systems of regulation, may actually increase the likelihood

\footnotetext{
${ }^{60}$ Estlund, Regoverning, 233-34.
} 
that enforcement deficits will be exacerbated rather than redressed. ${ }^{61}$ In that vein, Davies argues that the promotion of new governance theory can be fruitfully understood as a dimension of neoliberal hegemonic project that aims to secure consent through participation and the promotion of common interests, while the practice of new governance fails to deliver a new cooperative social order because it is undermined by the neoliberal material conditions in which new governance practices are enacted.62

\section{Alternative Paths}

Clearly, one path of new governance practice is toward more self governance, with the real danger that it will produce neo-liberal or at best paternalist regimes. As Tombs and Whyte have demonstrated, this is the path that has been followed in the UK. ${ }^{63}$ From Estlund's perspective, the self-regulation train has left the station and so there is no alternative but to work within that framework and try to steer it toward more worker protection. If that is true, then indeed our options are limited and the prospects for regulatory renewal are dismal. The question I want to pose here is whether there are alternative paths, and if so, whether a progressive new governance theory has anything to offer. My answer to both these questions is a tentative yes; that a regime that maintains a strong public enforcement focus is still possible and that a theory that focuses on ways to

\footnotetext{
${ }^{61}$ For another critique of new governance theory applied to enforcement deficits, see Guy Davidov, "The Enforcement Crisis in Labour Law and the Fallacy of Voluntarist Solutions (2010) 26 International Journal of Comparative Labour Law and Industrial Relations 61. Also see, Harish C. Jain et al., "Effectiveness of Canada's Employment Equity Legislation for Women (1997-2004): Implications for Policy Makers" (2010) 65 Relations Industrielles 304 (criticizing the lack of enforcement in the employment equity laws that primarily rely on mandated internal responsibility and reporting) and Shelley Marshall, "Australian Textile Clothing and Footwear Supply Chain Regulation" in Colin Fenwick and Tonia Novitz, eds., Human Rights at Work (Oxford: Hart, 2010), 555 (indicating that a reflexive regulatory scheme has made failed to improve the condition of Australian outworkers). ${ }^{62}$ Davies, Challenging Governanace.

${ }^{63}$ Steve Tombs and David Whyte, "A Deadly Consensus: Worker Safety and Regulatory Degradation under New Labour” (2010) 50 British Journal of Criminology 46.
} 
mobilize civil society forces in aid of public enforcement can indeed make a contribution to the development of effective OHS regulation in the context of the new world of work.

First, in regard to the possibility of regulatory alternatives that retain a strong public enforcement component, let us return to the case of Ontario. As we saw earlier, at the beginning of the 1990s it was looking as if the regime of mandated partial selfregulation was going to degrade as state enforcement was ebbing and worker OHS activism was subsiding. Subsequent events, however, tell a more complicated story, one that points to the possibility that the trajectory of public enforcement is not necessarily downward sloping, even under unfavourable political and economic conditions.

In 1995 an ideologically right wing government was elected and it attacked collective bargaining and employment standards laws. But it did not go after OHS. Indeed, the enforcement effort actually began to intensify and this upward trend has continued since the election of a Liberal government in 2003, although it has dipped slightly in the past couple of years. ${ }^{64}$ Evidence of this can be seen in the number of inspections, orders issues, stop worker orders and prosecutions (Charts 1-3). Of course, some of this increase may reflect the desire of government to pump up numbers. It is easy enough to manufacture the appearance of enforcement intensification by having more superficial inspections and issuing more trivial orders, but this explanation is belied by a concomitant increase in the use of stronger enforcement powers, notably stop work orders and convictions.

\footnotetext{
${ }^{64}$ Eric Tucker, "Diverging Trends," 409-412.
} 


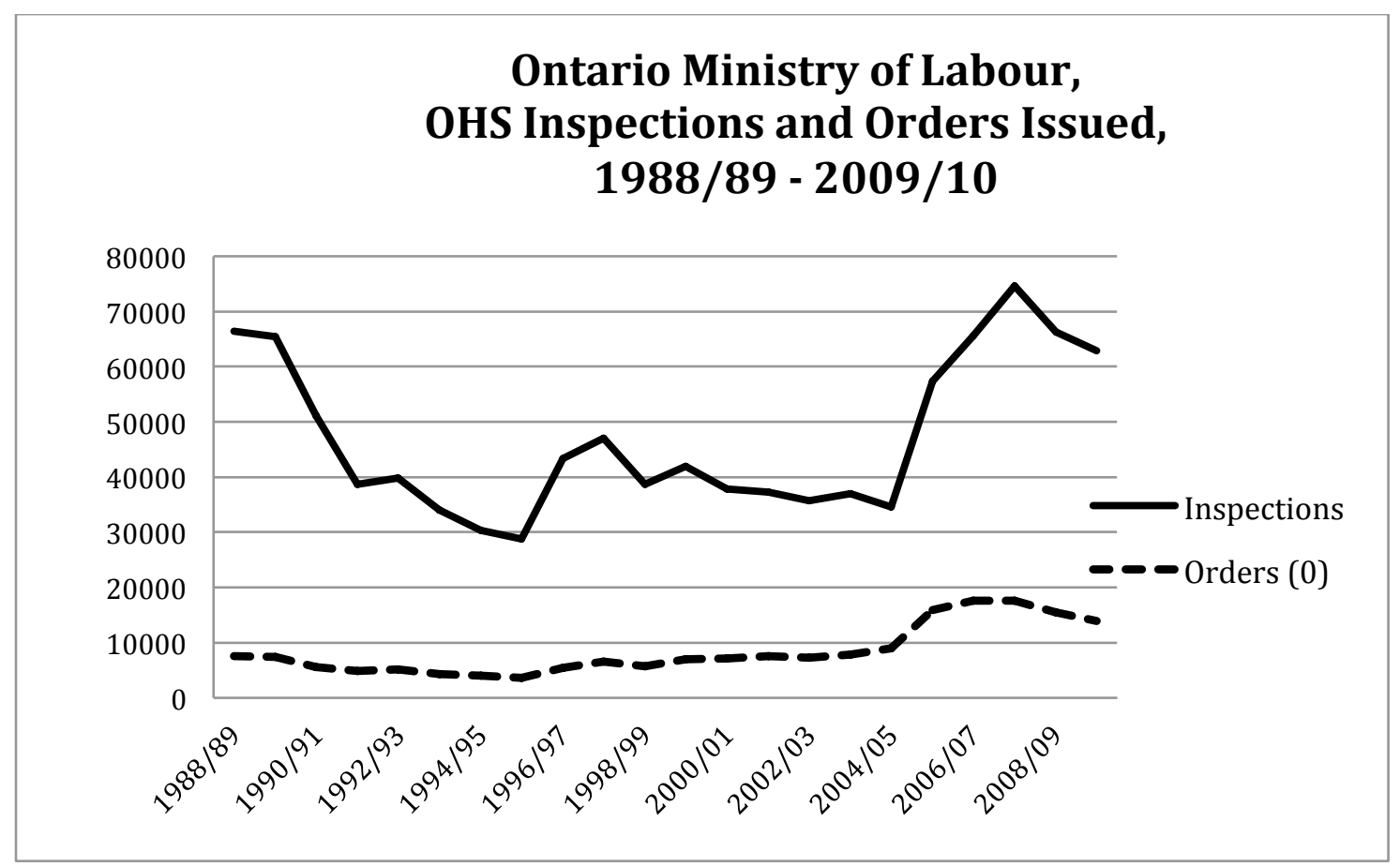

\section{Chart 1}

(Source: Ontario Ministry of Labour, Enforcement Statistics, various years)

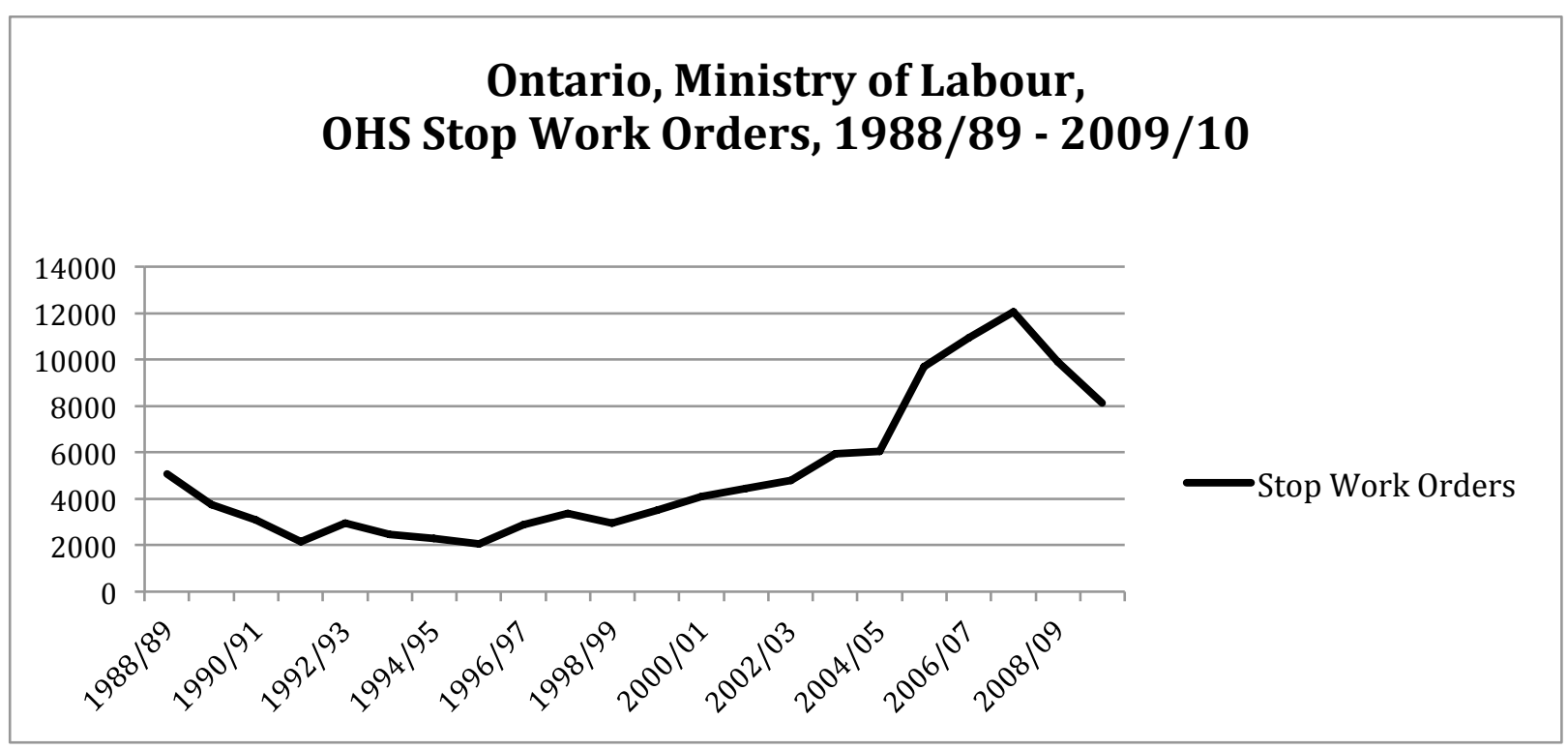

Chart 2

(Source: Ontario Ministry of Labour, Enforcement Statistics, various years ) 


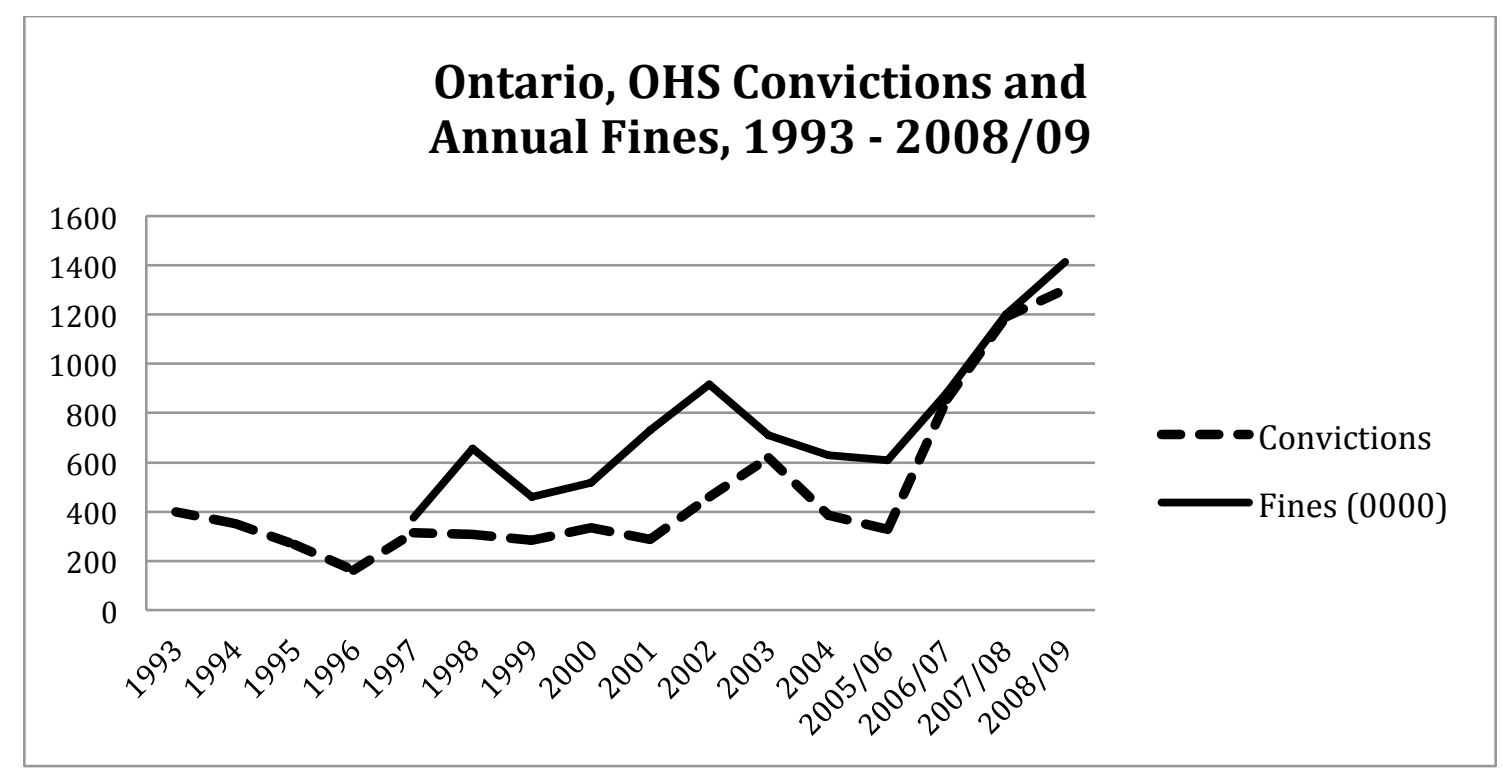

\section{Chart 3}

(Source: Ontario Ministry of Labour, Enforcement Statistics, various years)

The news is not all good. The number of convictions, particularly after 2005 , is inflated by the expansion of a ticketing system that allows inspectors to lay on-the-spot charges against workers, supervisors and employers for a variety of OHS violations. In practice, workers and supervisors each receive about $37 \%$ of summonses, while employers receive 25\%. As Garry Grey notes, the targeting of workers and front-line supervisors blurs the definition of who is an OHS offender and diffuses responsibility. ${ }^{65}$ It also has resulted in a reduction in the average fine per conviction (Chart 4).

\footnotetext{
${ }^{65}$ Garry C. Gray, "The Responsibilization Strategy of Health and Safety” (2009) 49 British Journal of Criminology 326.
} 


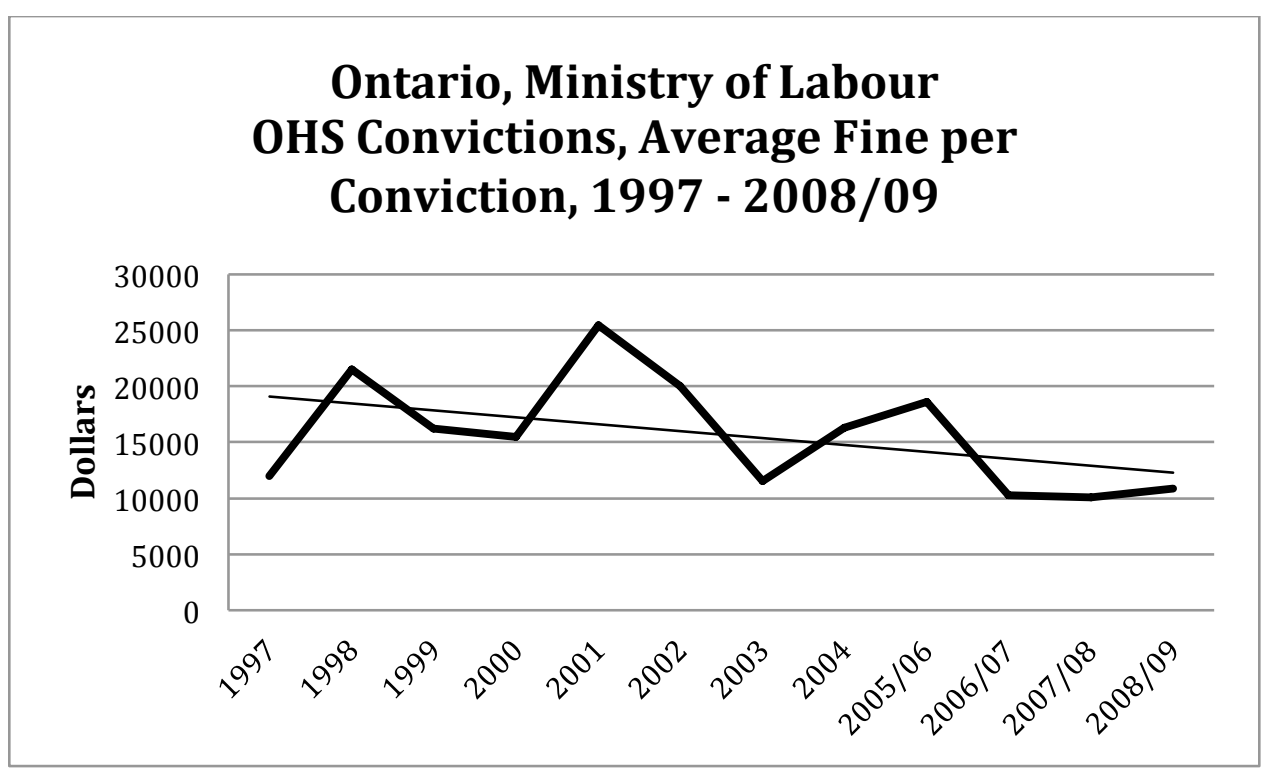

Chart 4

(Source: Ontario Ministry of Labour, Enforcement Statistics, various years; calculations by author)

In order to assess trends in more serious prosecutions under Part III of the Provincial Offences Act, disaggregated data was obtained from the Legal Services Branch for three years, $2007 / 08$ to $2009 / 10$. The data show that while there has been an increase in Part III prosecutions over these years, from 369 to 445, the average fine per conviction for these more serious offences declined from $\$ 35,303$ to $\$ 28,839.66$

It is also noteworthy that there has been little use of the criminal sanctions notwithstanding the enactment of Bill C-45, the so-called Westray Bill, which came into force in 2004 and was supposed to facilitate prosecution of OHS crimes. ${ }^{67}$ Across Canada, less than ten criminal charges have been laid. Three criminal cases have been brought in Ontario. The first criminal charge arose out of a ditch collapse that killed a worker in

\footnotetext{
${ }^{66}$ Special data run, Legal Services Branch, April 2011 (in possession of author).

${ }^{67}$ For a critical assessment of the legislation that has arguably been borne out by its application, see Steven Bittle and Laureen Snider, "From Manslaughter to Preventable Accident: Shaping Corporate Criminal Liability" (2006), 28 Law \& Policy 470.
} 
Newmarket, Ontario. The charge was laid in 2004 and was resolved by a plea deal in which the criminal charge was dropped in exchange for a guilty plea to violations under the OHS statute. ${ }^{68}$ The second criminal prosecution in Ontario was launched against Millenium Crane, the company's owner, and the crane operator at the time. In this case too the charges were dropped after an engineering report failed to support the prosecution's case. ${ }^{69}$ The third prosecution, which is pending at the time of writing, arose out of a scaffolding collapse that killed four workers on Christmas Eve 2009. The accused include the Metron Construction Co. and three of its officials. ${ }^{70}$

In Quebec two criminal cases have resulted in convictions. In Transpavé Inc., involving a workplace fatality, the accused pleaded guilty and was fined $\$ 110,000.00 .{ }^{71}$ The first conviction after a trial was obtained against Pasquale Scrocca, a landscape contractor. In that case, an employee died when the brakes on a backhoe Mr. Scrocca was driving failed, pinning the employee against a wall. Scrocca received a conditional sentence of imprisonment for two years less a day to be served in the community. ${ }^{72}$ One case, $R$. $v$. Gagné, Steve Lemieux and Simon Gagné, ended with an acquittal. In that case, charges were laid following a collision between a train and a maintenance vehicle, which resulted in one death and three injuries. The two accused individuals were employees of Québec-Cartier:

\footnotetext{
${ }^{68}$ Cheryl Edwards, "Where Are All the C-45 OHS Prosecutions?" http://www.heenanblaikie.com/en/media/pdfs/pdf/Where_Are_All the_Bill_C45 Prosecutions.pdf;jsessionid=94884D7F485727D18FFBDE0ED30ABFCA (visited 8 August 2011).

69 "C-45 Charges Against Ontario Crane Company Dropped" Canadian Employment Law Today (4 January 2011) http://www.employmentlawtoday.com/ArticleView.aspx?1=1\&articleid=2450 (visited 8 August 2011).

${ }^{70}$ Norm Keith, "Regulators Gone Wild!” Canadian Occupational Health and Safety (27 January 2011) http:/www.cos-mag.com/Legal/Legal-Columns/regulators-gone-wild.html (visited 8 August 2011).

${ }^{71}$ R. v. Transpavé Inc. 2008 QCCQ 1598.

${ }^{72}$ R. v. Scrocca, 2010 QCCQ 8218.
} 
Steve Lemieux, was the train operator, and Simon Gagné, was a foreman. Justice Dionne found that the mistakes made by the employees arose from a corporate culture of tolerance and deficient training, not wanton and reckless disregard for the lives and safety of workers on the part of the accused. In principle, this finding could have resulted in a conviction of the corporation, but it had not been charged..$^{73}$ There is at least one case still pending, against Mark Hritchuk, the service manager at a car dealership, where an employee died after catching fire due to a broken fuel pump..$^{74}$

Finally, in British Columbia, the United Steel Workers launched a private prosecution in 2010, arising out of the death of a Weyerhauser employee in British Columbia in 2004 . The company was previously assessed a penalty of nearly $\$ 300,000$ by the $\mathrm{BC}$ compensation board. A court has ruled that the union presented enough evidence for the case to go forward, but the Crown subsequently intervened to terminate the prosecution..$^{75}$

The targeting of workers and low-level supervisors in both OHS and Criminal Code prosecutions and the failure to aggressively use the criminal law should not obscure the positive side of the enforcement data, which reflect an increase in inspectors generally, and of proactive inspections in particular that target high-risk firms and, through planned

\footnotetext{
732010 QCCQ 12364; Norman Keith and Anna Abbott, “Acquittal in Quebec Bill C-45 Charges” (Online http://www.gowlings.com/KnowledgeCentre/enewsletters/ohslaw/htmfiles/ohslaw20110427.en.html).

${ }^{74}$ Stefan Dubowski, "Complexity, Confusion Stymies C-45 Charges." Canadian Occupational Health and Safety (1 November 2010) http://www.cos-mag.com/Legal/Legal-Stories/Complexity-confusion-stymies-C-45-charges.html (visited 8 August 2011).

${ }^{75}$ BC Court: Union's Private Criminal Negligence Case Can Go Forward." OHS Insider 8 March 2011) online: http://ohsinsider.com/search-by-index/c45/bc-court-union\%E2\%80\%99s-private-criminalnegligence-prosecution-can-go-forward [accessed: 8 August 2011]; “Alert: Crown Dismisses Union Brought C-45 Case." OHS Insider (25 August 2011). Online http://ohsinsider.com/search-byindex/c45/aug-25-crown-dismisses-union-brought-c-45-case [accessed 5 September 2011].
} 
safety blitzes, high-risk hazards. ${ }^{76}$ However, workers can never be complacent about the gains they make in improved enforcement. Since the beginning of the recession in 2008, which has hit Ontario particularly hard, there has been a dip in enforcement activity and there is a risk that as the government moves to trim its budget enforcement resources will be lost. There has already been a shift in employment standards enforcement, toward a self-reliance model that places more responsibility of workers to pursue their claims with their employers as part of the government's open for business agenda. ${ }^{77}$

The recent report of the Expert Advisory Panel on Occupational Health and Safety (Dean Report) did not make strong recommendations on enforcement, seeking instead to accommodate the concerns expressed to it by employer and labour stakeholders. Thus is called for "a consistent approach of tough enforcement for serious and wilful contraventions, as well as compliance assistance where guidance and support for employers help achieve compliance" The report called for a review of the ticketing system, with an eye toward increasing set fines, and for the addition of administrative monetary

\footnotetext{
${ }^{76}$ For a description on Onatrio's OHS enforcement strategy, see http://www.labour.gov.on.ca/english/hs/sawo/index.php (visited 13 April 2011). For a study that supports the efficacy of a blitz strategy in the context of workplace discrimination, see C. Elizabeth Hirsh, "The Strength of Weak Enforcement: The Impact of Discrimination Charges, Legal Environments, and Organizational Conditions on Workplace Segregation" (2009), 74 American Sociological Review 245.

${ }^{77}$ Open for Business Act, S.O. 2010, c. 16, Sch. 9, s. 1. For a critique, see Workers Action Centre and Parkdale Community Legal Services, Submission to the Standing Committee on Finance and Economic Affairs regarding Schedule 9, Bill 68, An Act to promote Ontario as open for business by amending or repealing certain Acts (26 July 2010). Online http://www.workersactioncentre.org/!docs/sb_Bill68_eng.pdf (visited 14 Oct. 2011).
} 
penalties as an enforcement tool. ${ }^{78}$ It remains to be seen how the government will respond to these recommendations.

Data on the strength of worker participation is harder to come by, but what little there is suggests that it has weakened over the past decade or so. One study comparing IRS systems in 1990 and 2001 found that worker influence seemed to be in decline. Managers viewed worker participation as less important and perceived that management bargaining strength over OHS had increased. Worker representatives saw management as less cooperative and perceived that workers were more likely to be hassled by co-workers for raising health and safety issues or filing a workers' compensation claim. ${ }^{79}$ Another possible measure, albeit one that is subject to alternate interpretations, is the number of work refusals reported to the Ministry of Labour. ${ }^{80}$ To the extent that they tell us something about worker OHS activism, the trend over most of this decade has been downwards (Chart 5). The recession of 2008 undoubtedly has exacerbated worker fear of job loss and dampened their willingness to be militant around OHS issues.

\footnotetext{
${ }^{78}$ Ontario. Expert Advisory Panel on Occupational Health and Safety, Report and Recommendations to the Minister of Labour (December 2010) online at http://www.labour.gov.on.ca/english/hs/pdf/eap report.pdf, (Dean Report), 42-44. For a more detailed discussion of the Dean Report, see Lewchuk, this volume.

${ }^{79}$ Sybil Geldart, Harry S. Shannon, and Lynne Lohfeld, "Have Companies Improved Their Health and Safety Approaches Over the Last Decade? A Longitudinal Study" (2005) 47 American Journal of Industrial Medicine 22736).

${ }^{80}$ For an insightful analysis of work refusal behavior, see Garry C. Gray, "A Socio-Legal Ethnography of the Right to Refuse Dangerous Work" (2002), 24 Studies in Law, Politics and Society 133.
} 


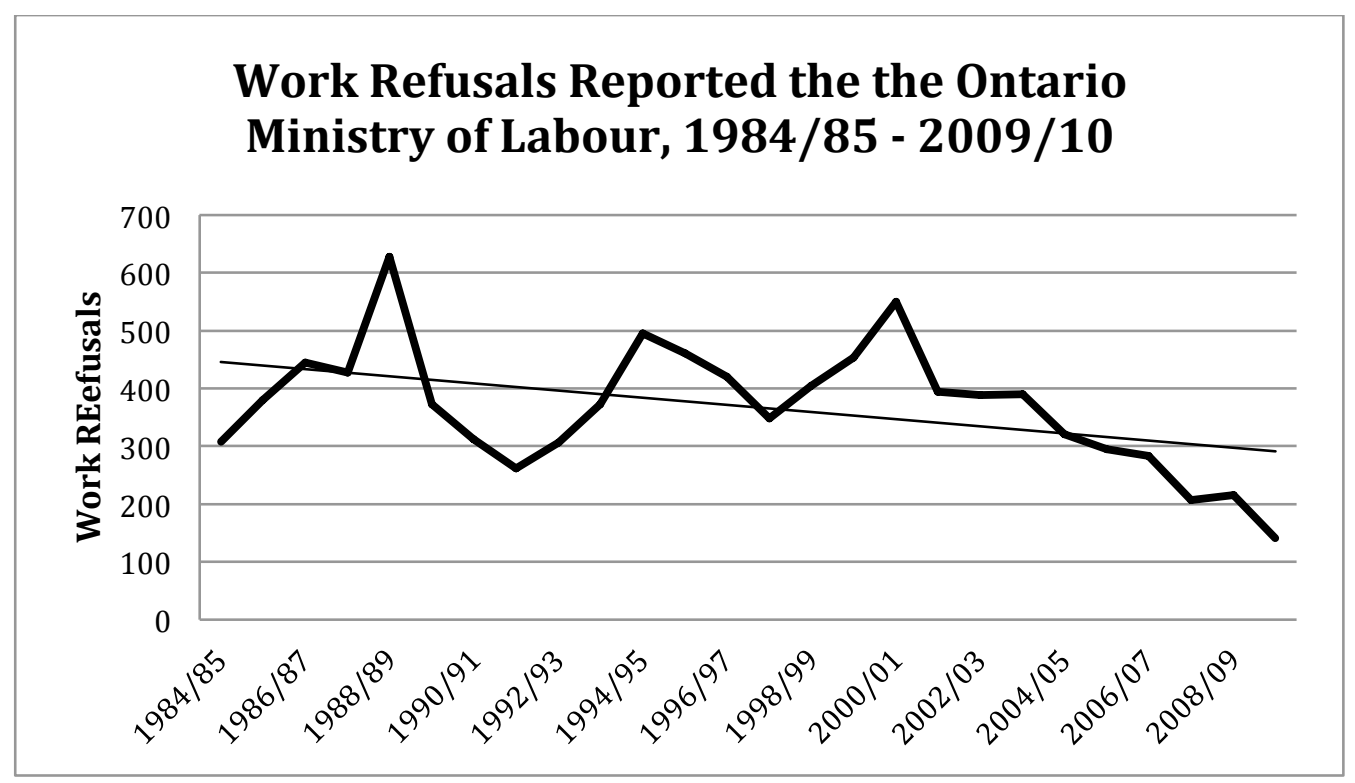

\section{Chart 5}

(Source: Ontario Ministry of Labour, Enforcement Statistics, various years)

The decline in private sector union density in Canada over the past three decades, from nearly $30 \%$ in 1981 to just over $16 \%$ in 2009, would be consistent with decreased worker OHS activism of all kinds, given the significant link researchers have found between union representation and the effectiveness of worker participation. ${ }^{81}$ The drop in union density also translates into reduced bargaining power and militancy, as is reflected in the sharp drop in strike incidence since 1976 (Chart 6).

\footnotetext{
${ }^{81}$ For example, see Theo Nichols and David Walters, "Worker Representation on Health and Safety in the UK Problems with the Preferred Model and Beyond" in Walters and Nichols, eds., Workplace Health and Safety 19; Wayne Lewchuk et al, "The Effectiveness of Bill 70 and Joint Health and Safety Committees in Reducing Injuries in the Workplace: The Case of Ontario" (1996), 23 Canadian Public Policy 225.
} 


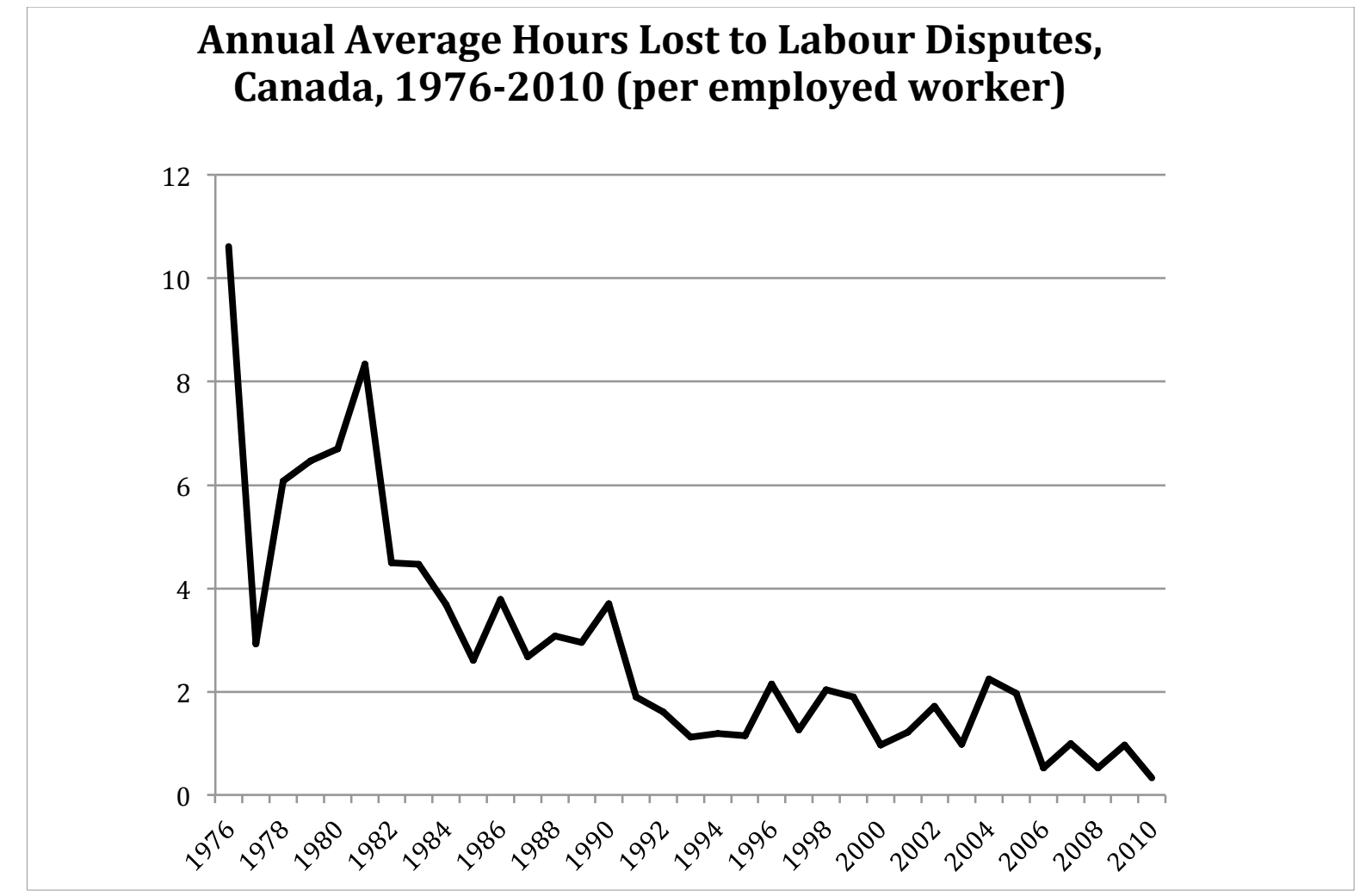

Chart 6

(Source: HRSDC, http://www4.hrsdc.gc.ca/.3ndic.1t.4r@-eng.jsp?iid=14)

The Dean Report recognized that more needed to be done to support worker participation in the IRS and made a number of recommendations, including: a measure to permit worker chairs of JHSC to submit written recommendations to the employer when the JHSC is deadlocked; mandatory training of health and safety representatives in small (6-19) workplaces; and improved protection from reprisals. ${ }^{82}$ These recommendations were acted upon by the government. 83

Assessing the strength of employer OHS management is even more difficult. One study found that on several measures OHS management improved between 1990 and

\footnotetext{
${ }^{82}$ Dean Report, 28-31, 49-51.

${ }^{83}$ S.O. 2011 , c. 11 .
} 
2001. Senior managers were more directly involved in safety, safety was more likely to be included in managerial job descriptions, and more safety training was provided to workers. ${ }^{84}$ It is also possible that increased experience rating has created an economic incentive to better manage safety, although the evidence is decidedly mixed with studies showing that the most frequent response of employers is to control claims cost, often through aggressive claims management. ${ }^{85}$ On the other hand, the growth of small business and de-centralized production is likely to have had a negative impact on the overall capacity of employers to manage OHS. ${ }^{86}$

The Dean Report also made some recommendations to enhance employer capacity, competence and commitment to manage OHS risks. These include mandatory OHS training for supervisors responsible for frontline workers, an accreditation system for employers that successfully implement OHS management systems, appropriate financial incentives for firms that qualify suppliers based on their OHS performance, and more compliance assistance from inspectors. It also made recommendations aimed at improving compliance in the small business sector. Importantly, none of the proposals are offered as alternatives to strong enforcement and worker participation. For example, there is no suggestion that accredited employers should be exempt from routine inspections and the report is clear

\footnotetext{
${ }^{84}$ Geldart et al.; A related study found that firms with better OHS management had lower lost-time injury rates. See Sybil Geldart et al., "Organizational Practices and Workplace Health and Safety: A Cross-Sectional Study in Manufacturing Companies" (2010) 48 Safety Science 562.

${ }^{85}$ Emile Tompa, Scott Trevithick and Chris McLeod, "Systematic Review of the Prevention Incentives of Insurance and Regulatory Mechanisms for Occupational Health and Safety" (2007) 33 Scandinavian Journal of Work, Environment \& Health 85; Michele Campolieti, Douglas Hyatt and Terry Thomason, "Experience Rating, Work Injuries and Benefit Costs: Some New Evidence" (2006) 61 Relations Industrielles 118.

${ }^{86}$ Michael Quinlan, "The Implications of Labour Market Restructuring in Industrialized Societies for Occupational Health and Safety" (1999), 20Economic and Industrial Democracy 427; Joan Eakin, "'Leaving it Up to the Workers': Sociological Perspective on the Management of Health and Safety in Small Workplaces" (1992), 22 International Journal of Health Services 689.
} 
that more compliance assistance "should not interfere with the inspector's duty to enforce the law." Moreover, the report also recognizes that financial incentives should not be based primarily on claims cost and frequency. ${ }^{87}$

The relevance of Ontario's recent OHS regime lies in the fact that it provides evidence that neo-liberal self regulation/paternalism is not the inevitable destination of Robens style regimes. Indeed, it indicates that after a regime starts down the neo-liberal path, as was the case in Ontario (ironically under the auspices of a labour friendly government), its direction can be changed, even with a conservative government in power. It is beyond the scope of this intervention to endeavour to provide an explanation for this development, ${ }^{88}$ other than to suggest that perhaps in some way the assignment of prevention activities to the Workplace Safety and Insurance Board, where a discourse of partnership and 'safety pays' predominates, created more space for the MOL to define its mandate as that of setting and enforcing standards. If that is true, then the principal recommendation of the Dean Report to move prevention activities back into the Ministry of Labour, a recommendation that the government has already implemented, may pose the risk of a re-orientation away from enforcement. ${ }^{89}$ Moreover, the recent dip in enforcement activity is a timely reminder of the difficulty of maintaining a strong programme of proactive enforcement in the face of a recession which has resulted in significant job loss, particularly in the manufacturing sector..$^{90}$

\footnotetext{
${ }^{87}$ Dean Report, 53. Also see, 34 (supervisor training), and 37-42 (incentives). On March 3, 2011, the government introduced Bill 160 to implement some of the Dean Report's recommendations.

${ }^{88}$ Elsewhere I tried to explain diverges between selected Canadian jurisdictions based on trade union density, employer size, etc. Tucker, "Diverging Trends."

${ }^{89}$ S.O. 2011, c. 11.

${ }^{90}$ For recent data, see Canada, HRSDC, Labour Market Bulletin (Fall 2011), http://www.hrsdc.gc.ca/eng/workplaceskills/labour_market_information/bulletins/on/on-lmb-2011fall.pdf.
} 
This brings us back to the final question I want to address, which is whether a progressive new governance theory has anything to offer. Here I turn briefly to recent work by Gordon and Fine who start from the same premise of folks like Lobel and Estlund that existing forms of command and control regulation are deficient and that moving forward will require the mobilization of civil society forces. However, unlike Lobel and Estlund, they reject the turn toward self-regulation as inevitable or desirable. Rather, their project aims to engage workers as monitors in public enforcement. ${ }^{91}$ Their particular concern is the enforcement of labour standards, particularly hours of work and minimum wages, and this dictates a focus on vulnerable workers in the non-union sector - the paradigm case of the new world of work. Given a world in which state enforcement is chronically under-resourced, unions have limited reach and the incidence and distribution of complaints is unlikely to reflect the pattern of actual violations, ${ }^{92}$ their recommendations aim to develop a system of third-party worker representatives who can extend the reach of public enforcement into sectors of the labour market where workers are at high risk of violations but also less well protected. These third-parties could be unions with roots in a particular industry, but could also include workers' centres or other workers' organizations. For worker organizations to have a meaningful impact on enforcement, Fine and Gordon stipulate that collaborations with government must be formalized, sustained and vigorous, and adequately resourced. They suggest a number of models, ranging from

\footnotetext{
${ }^{91}$ Janice Fine and Jennifer Gordon, "Strengthening Labor Standards Enforcement through Partnership with Workers Organizations (2010) 38 Politics \& Society 552; and "Beyond the New Regulatory Scholarship: Strengthening the Role of State and Civil Society in Labor Standards Enforcement" (unpublished).

${ }_{92}$ David Weil and Amanda Pyles, "Why Complain? Complaints, Compliance, and the Problem of Enforcement in the U.S. Workplace" (2005) 27 Comparative Labor Law and Policy Journal 59.
} 
deputizing persons associated with workers' organizations to designating workers' organizations as sites where workers can anonymously register complaints to having workers' organizations provide enforcers with intelligence that would assist them in identifying high risk employers or industries.

In some ways, their proposal resembles the Swedish regional safety representative system, except that the focus here is much less on providing assistance to the IRS than on strengthening the ERS. It is also a model that can be used by unionized workers in their own workplaces. For example, the Canadian Auto Workers recently reported on the efforts of a local that represents federally regulated workers in the airline industry to build relationships with federal OHS inspectors so that they can more easily be called upon to intervene when the union is unable to secure satisfactory responses from their employers. ${ }^{93}$

The approach advocated by Fine and Gordon faces many obstacles and may not be realized except on an exceptional basis. Nevertheless, the priority given to building pubic enforcement and enhancing worker participation - that is toward building a worker democratic regime - arguably has more potential in the long run than a 'new' new governance alternative that relegates these elements to a secondary and supporting role in a regime that gives primacy to employer self-regulation.

\section{Conclusion}

For the most part, 'new' new governance theories are rooted in the same consensus theory that informed 'old' new governance theory as articulated by the Robens Report and

\footnotetext{
${ }^{93}$ Ian Bennie, Ben Bachl and Rossanna Dewey, "Success, One Small Step at a Time" CAW Health, Safety Environment Newsletter (Sept.-Dec. 2010), 3.
} 
that was so effectively criticized by Nichols and Armstrong nearly 40 years ago. Lobel and Estlund are sensitive to the salience of power imbalances and conflicts of interest and, therefore, call for robust worker participation and public enforcement as adjuncts to a regime of regulated self-regulation. However, for both, worker participation and public enforcement are truly secondary. Lobel justifies a focus on self-regulation by minimizing the extent of conflict over OHS, while Estlund sees there is no alternative and therefore efforts must focus on steering self-regulation toward more effective worker protection. I argue their policy prescriptions are more likely to lead toward neo-liberal self regulation/paternalism than toward worker or social democracy. The example of enforcement in Ontario suggests that the trend toward more self-regulation is not inevitable and that Gordon and Fine's strategy of enhancing public regulation and enforcement through partnerships with worker organizations is feasible and promising. Of course there are significant limits to what can be accomplished in an increasingly neoliberal capitalist social formation, which exacerbates the structural pressure to put profit over safety, but there is ample evidence that employers who are inspected and sanctioned for OHS violations become more actively engaged in workplace prevention. ${ }^{94}$ Indeed, the authors of one recent study conclude that "to confine the role of prosecution to a measure of last resort, then, is not only without empirical foundation, but also likely to send the 'wrong message' to employers about how the problem of serious OHS offences is

\footnotetext{
${ }^{94}$ For a recent literature review, see Kevin Purse and Jillian Dorrian, "Deterrence and Enforcement of Occupational Health and Safety Law" (2011), 27 International Journal of Comparative Labour Law and Industrial Relations 23.
} 
understood by regulatory authorities and in civil society more broadly."95 In short, instead of new governance approaches that depend on common interest or the mobilization of market forces by civil society groups, we are better off developing strategies that concentrate on strengthening worker voice and public regulation. ${ }^{96}$ At the very least, such an approach avoids valorizing a set of assumptions and practices that, as Nichols and Armstrong demonstrated, historically have served workers poorly.

\footnotetext{
95 Toni Schofield, Belinda Reeve and Ron McCallum, “Deterrence and OHS Prosecutions: Prosecuted Employers' Responses" (2009), 25 Journal of Occupational Health and Safety - Australia and New Zealand 263 at 275.

${ }^{96}$ David Weil's work on enforcement is particularly helpful. For example, see David Weil, Improving Workplace Conditions Through Strategic Enforcement (Report to the Wage and Hour Division, May 2010) online at http://papers.ssrn.com/sol3/papers.cfm?abstract_id=1623390.
} 